\title{
Research on Computer Teaching Reform in Colleges and Universities
}

\author{
Qiu Jing YANG \\ Chongqing Business Vocational College \\ Associate professor \\ ChongQing, China \\ 12258962@qq.com
}

\begin{abstract}
In recent years, with the rapid development and application of computer technology, computer knowledge and ability have become important skills for contemporary college students to obtain employment. Under such circumstances, it is required that colleges and universities must increase the investment in university computer education so that students can acquire relevant knowledge of computer technology and application and lay a good foundation for future employment. Therefore, in the process of university teaching, through computer teaching reform, the university computer teaching is more adapted to the continuous development of computer science and technology and the new demands of social progress on college students' computer skills, and to cultivate students' awareness and ability to use computers to analyze problems and solve problems. It is of great practical significance and is also a new topic faced by colleges and universities in the process of development.
\end{abstract}

\section{Keywords-Computer teaching reform; Colleges; Universities}

\section{INTRODUCTION}

At present, the rapid popularization of computer technology and the rapid development of network technology have made college computer teaching enter a new period of reform. However, the computer science students cultivated in modern colleges and universities and the social market do not match the needs of relevant professionals. Many computer graduates in colleges and universities are not able to perform practical tasks. Therefore, how to adjust the training objectives of computer talents in colleges and universities and deepen the reform of computer teaching in accordance with the changes in market demand is an important issue facing university computer research.

\section{PRoblems IN COMPUTER TEACHING IN COLLEGES AND UNIVERSITIES}

\section{A. The Teaching Content is Old}

The computer has a very fast update speed, which makes the computer facilities such as software facilities, hardware facilities, and systems have a high elimination rate. Therefore, in computer teaching in colleges and universities, it is necessary to actually start, advance with the times, and make students the full understanding and mastery of the nature of computer teaching. However, in today's university computer teaching, many textbooks are relatively old, and the compilation and selection of textbooks lags far behind the speed of development of computer information technology. In addition, there are irrational situations in the setting up of computer teaching courses in schools, and the phenomenon of heavy theoretical experiments is common. Many students need to further train after they graduate and work in enterprises. This will be used for teaching resources in colleges and universities. Very large waste has also caused great restrictions on the development of our country's teaching.

\section{B. The Simplification of Teaching Methods.}

The computer science discipline is different from other basic disciplines. It focuses on the combination of theory and practice. Usually, the practice will be more important. In teaching, teachers should use scientific methods and innovative methods to teach students theoretically in the classroom and use other resources to guide students in order to cultivate their practical ability. However, in today's college computer teaching, a single teaching method exists universally, teaching methods are relatively backward, making students passively accept the knowledge instilled by teachers, but not to actively explore knowledge, ignoring the use of advanced teaching methods to carry out teaching.

\section{The Teaching Methods are Fixed.}

The main task of computer teaching in colleges and universities is to use advanced teaching methods to cultivate students' innovative and practical abilities. However, many teachers in universities and colleges pay attention to the use of traditional teaching methods, such as teachers' mechanical teaching and students' blind acceptance. Students often study computers. 


\section{Abstraction of Teaching Curriculum.}

At present, computer courses arranged and set up in college computer teaching also have some problems. For example, in some non-professional computer classrooms, courses such as "office automation" or "basic programming" still occupy an important position. Since computers in the modern society have been widely used, the curriculum understood by students has already exceeded the scope of the curriculum. Many students have already had a certain level of operation before learning knowledge. Therefore, if the knowledge are blindly instilled in the minds of students, students will become bored and tedious, reducing the enthusiasm for learning and the quality of learning.

\section{E. Thickness of Teaching Management.}

Due to the bad influence of traditional exam-oriented education, colleges and universities basically evaluate and test in the form of exams, and cannot fundamentally meet the requirements for upgrading the quality of computer talents. In addition, many colleges and universities often use "extensive" management methods when managing computer equipment and computer factory buildings, which greatly reduce teaching effectiveness.

\section{F. Formalization of Teaching Objectives.}

At present, computer teaching in many colleges and universities takes examination results as the assessment criteria, and it is still at an exploratory stage in cultivating students' practical operation ability. In arranging and setting teaching goals is not combined with the needs of today's society for talent, many students failed in computer theory, the operation of the software and hardware operation is not very skilled. The teaching objectives limit the development of students' personalities and affect the overall improvement of computer teaching in China.

\section{THE NECESSITY OF COMPUTER TEACHING REFORM IN COLLEGES AND UNIVERSITIES}

\section{A. At Present, There are Differences in the Contents of Teaching in Colleges and Universities and Social Needs.}

At present, the contents of computer teaching programs in universities in our country are more theoretical and do not combine social and work-related needs. The teaching content arranged by many colleges and universities is not innovative, and the teaching content is relatively old and practical. At present, the replacement time in Chinese computer industry is very short, and computer software and hardware system equipment are highly eliminated. However, too old and theoretical teaching content and the inability to meet the computer industry, which is currently being updated quickly, cannot be applied to practical work. Graduates need to be trained before they go to work. This will not only lead to a waste of educational resources, limit the development of students, but also increase the cost of employers. From this point of view, computer teaching reform is very necessary.

\section{B. Traditional Computer Teaching Lacks Practicality.}

At present, there are many areas where traditional education concepts and education models in China need to be improved. Computer teaching in many colleges and universities is influenced by traditional teaching concepts and models, and traditional duck-feeding teaching models are still used. This teaching model does not regard students as the main body, and students are often passive. Location, practice training is relatively low. The reason for these phenomena is that many colleges and universities do not recognize the importance of computer practical teaching. The traditional teaching model has the wrong theory of heavy theory and light practice, and cannot train students into comprehensive talents with strong practicality and hands-on ability, which has a certain degree of adverse impact on the quality of computer teaching in colleges and universities.

\section{The Measures of College Computer Teaching REFORM}

\section{A. Improve Teaching Content and Optimize Teaching Methods.}

First of all, computer technology has developed rapidly, and replacement is fast. Therefore, it is necessary to ensure the scientificity and advancement of the content of computer series courses. This has very important practical significance for cultivating college students' adaptability to society. Therefore, it is necessary to update the contents of computer teaching along with the development of computer technology, and on this basis, to improve the interrelationship between the teaching content of computer courses and other professional courses, and to ensure that students' computer courses are studied together with other disciplines to maintain their integrity. Second, the computer teaching course is a highly-skilled course, and sometimes it is boring to learn. Therefore, computer teaching should be based on the actual situation of colleges and universities as well as the individual situation of students, and adopt different teaching methods to inspire students to learn. For example, multimedia teaching and network teaching can be combined to give full play to the function of spreading knowledge on the Internet. On the one hand, it can fully display the rich connotation of computer science. At the same time, it is also helpful for students to broaden their horizons and inspire their interest in learning. Again, regular computerrelated lectures are held. Through the computer knowledge lectures, students' interest in learning can be improved. Students can also learn about the latest computer knowledge. The rich knowledge and connotation of the lecture teacher itself is also an incentive for college students. In order to further improve the quality of teaching, it is important to innovate course assessment methods. On the one hand, we must strengthen the management of the teaching process, incorporate the performance of college students in the daily teaching curriculum into the final assessment, and at the same time, in order to ensure the strictness, fairness, and impartiality of assessment, we must formulate a series of evaluation methods for computer courses, from multiple angles, All-round study of students' learning. In addition, when conducting yearend assessments, it is necessary to attach importance to the 
students' computer skills and to examine their practical abilities, and ultimately achieve the goal of fully cultivating students' computer application abilities. At the same time, in order to promote students' understanding of the content of computer teaching in the teaching process of colleges and universities, teachers should integrate the rich teaching methods into the computer teaching process and effectively promote the improvement of students' learning enthusiasm. In today's technologically advanced environment, network information technology and multimedia teaching technology have become indispensable teaching methods in teaching activities. The application of multiple teaching methods can promote students' love of computer information technology and continuously improve traditional teaching methods. The intrinsic teaching mode can effectively promote students' understanding and mastery of computer knowledge through various teaching modes, and effectively improve students' proficiency in applying modern computer information technology through practical operations. Universities create a scientific framework of the data database and exchange platform for students, and enhance the students' use of teaching sites through the rational and effective integration of network resources. For example, college teachers can use the new micro-class teaching to promote the practical application of students' computer skills. They can also use the special nature of micro lessons to listen to students at any time to expand their learning approaches, and effectively increase their enthusiasm for computer learning.

\section{B. Increase Hardware Investment and Update Teaching Equipment.}

The difference between computers and other disciplines is that they are very practical and operational and require the provision of equipment and patience of teachers. Therefore, on the one hand, teachers are required to master the latest computer theory and information. Based on this, they can design and link practical teaching programs, allowing students to develop actual projects based on the actual situation. On the other hand, they must have enough stable computers. Students practice internships, students can master the curriculum knowledge through a large number of experiments on the machine, which requires the colleges and universities to have a sufficient number of computer hardware equipment and application software. At present, schools should gradually improve teaching facilities in accordance with the actual situation of the university to meet the needs of computer teaching. At the same time, schools should strengthen the construction of professional laboratories and make computer open laboratories a place and base for creative experimental teaching. On the one hand, it is necessary to increase the investment in teaching equipment for computer teaching, and colleges and universities need to provide advanced experimental conditions for teachers and students. They can add some audio-visual equipment and transmit various information carriers such as voice, text, pictures, and images to students in all directions. It is also possible to download or purchase some of the latest computer technology results from the Internet for student research, making it easier to receive and deliver new computer technologies. In addition, the laboratory should also set up monitoring procedures. Through the console screen, on the one hand, students can avoid irrelevant and nonlearning operations. At the same time, students can observe the operation process of the students. If they find that students have misoperation, teachers can promptly it provides counseling to improve the effectiveness of teaching.

\section{Focus on the Role of Computer Teaching Files.}

Computer teaching archives are the collection, classification, storage, storage and use of the computer teaching curriculum from the beginning to the end of its existence and development experience. It is of great reference and use value for future teaching management. This is the computer teaching management and computer teaching reform in the new era. Part of the work cannot be ignored in the work. First of all, the teaching archives will not change according to the subjective wishes of any person in the teaching management work. It will always maintain its own original appearance for teaching inquiry and use. Secondly, computer teaching files can provide reliable reference and utilization value for improving our actual teaching management level today. By this, we can continuously improve teaching methods and improve teaching efficiency. In addition, the archives have a feedback function. Regular analysis, classification and storage of these materials can promptly find useful information and information for teaching management, and help improve the level of teaching management. In a word, the computer teaching archives in the past have played a very important role in the teaching management of the new period. We should continue to conduct in-depth research on it and explore the effective teaching methods and rules reflected in the previous computer teaching archives to adapt to modern teaching. Manage and realize the need for its scientific management.

\section{Increase the Construction of Computer Teachers.}

The construction of the teaching staff is the most basic teaching construction in the school. Gradually establishing a team of qualified, well-qualified, relatively stable teachers is the key factor for computer teaching in the new era. At the same time, the rapid development of society at any time, computer technology updates are also changing with each passing day, followed by the teaching content of most of the computer professional courses are constantly updated changes, this also puts forward the construction and improvement of computer teaching teachers in colleges and universities High demand. On the one hand, schools should pay attention to cultivating the backbone of young teaching. They should provide computer teachers with more opportunities for advanced studies, and provide computer teachers with more opportunities to learn new knowledge and new software, so that they can acquire more new and refined skills. Sharp technology, so as to better dedicate and solve doubts, to ensure that the computer teachers' own knowledge level can advance with the times, and to ensure the improvement of classroom teaching and practical teaching, and promote the steady rise of teaching quality. Only in this way, can we adapt to the requirements of computer teachers in colleges and universities in the new situation. In training, it is necessary to focus on improving the professional skills of teachers, but also on the teacher's previous traditional teaching concepts, to enable them to quickly change roles, and actively use the students as the 
host of classroom teaching. At the same time, teachers should try their best to speed up their own transformation and development, that is, change from the past experience type to today's innovative type, from the previous type of education to the current professional-type compound talents. On the other hand, we must pay attention to the introduction of computer professionals to enrich the teaching staff, do a good job of building a ladder of teachers, and eventually build a relatively stable high-level and high-quality teacher team to meet the development needs of universities.

\section{E. Use a Variety of Means to Improve Student Interest in Learning.}

Classroom teaching time is limited, and learning is unlimited. College computer teaching reform should focus on cultivating students' interest in computers and motivate students to actively and actively study. Therefore, according to the conditions of the school, organized and planned computerrelated extra-curricular activities, such as programming, web page production, animation production, PPT courseware production, etc., even in a competitive way, will not only help students improve their computer skills. The interests of students are conducive to training students' teamwork ability and comprehensive application ability. This is undoubtedly very beneficial to improve students' computer application ability, how to solve problem-solving abilities, and the development of psychological quality in the face of difficulties.

Teaching activities are a complex process of two-way interaction between teachers and students, and information feedback among them is a key factor in controlling and regulating this process. Teachers' optimization and adjustment of teaching activities through the feedback of teaching activities is conducive to realizing and correcting the purpose of teaching activities, remedying the defects and inappropriateness in teaching activities, and correcting them so as to achieve the desired teaching effect. Computer teaching focuses on the use of knowledge and skills. In the process of practical teaching, teachers should pay attention to observing and recording students' operating procedures and answering procedures, and do a good job of information feedback. When it is found that the individual student's "feedback" is not effective, the teacher should ask some "implicit" questions to inspire them to continue to complete the exercises accurately. By recording the common problems that appear in the feedback information, teachers should correct their teaching methods in a timely manner and help students correct their learning methods Make a unified and in-depth analysis and explanation of key and difficult issues, together with students to study and discuss to complete teaching tasks, improve the quality of teaching, and promote the positive transfer of knowledge.

\section{CONCLUSION}

Among colleges and universities, computer has a very important practicality as a common teaching and work tool. College students must actively learn computer knowledge if they want to survive and develop in an increasingly fierce society. Colleges and universities should fully recognize this and vigorously promote the reform and development of computer teaching so as to better adapt to the development of students and the needs of society.

\section{REFERENCES}

[1] Zhang Hang. Discussion on Outstanding Practicality of College Computer Teaching Reform[J]. Heilongjiang Science and Technology Information, 2013 (2): 197.

[2] Sun Hua. Discuss the reform and development of computer teaching in Chinese universities [J]. China E-commerce, 2012(20): 111.

[3] Zhu Xiu-gang. A computer-based teaching method based on behavior orientation [J]. Success (Education), 2012 (11): 23 7-238.

[4] Wang Yan, Zheng Yingfeng. Analysis and research on the explicitness of hidden indicators in college computer education[J]. Computer Education, 2012 (16): 64-66.

[5] Fu Dalin,Ma Yingrui.Combination of Computer Teaching and Quality Education in Colleges and Universities $[\mathrm{J}]$. Century Bridge, 2012(7):135-136 